\title{
First isolation of Nocardia crassostreae from Pacific oyster Crassostrea gigas in Europe
}

\author{
Marc Y. Engelsma ${ }^{1, *}$, Ineke Roozenburg ${ }^{1}$, Jean-Pierre Joly ${ }^{2}$ \\ ${ }^{1}$ Central Veterinary Institute, Wageningen University and Research Centre, PO Box 2004, 8203 AA Lelystad, The Netherlands \\ ${ }^{2}$ Laboratoire de Génétique et Pathologie (LGP), Institut Français de Recherche pour l'Exploitation de la Mer (IFREMER), \\ 17390 La Tremblade, France
}

\begin{abstract}
In summer 2006 an extensive mortality of Pacific oysters Crassostrea gigas occurred in Lake Grevelingen, the Netherlands. A sample of Pacific oysters was investigated for the presence of shellfish pathogens as potential causes of the mortality. Yellow-green lesions were observed in several oysters upon clinical inspection. Histopathology showed that 6 out of 36 oysters had a suspected bacterial infection, including 4 Nocardia-like infections. Two bacterial species, Vibrio aestuarianus and Nocardia crassostreae, were isolated from haemolymph samples and identified using PCR and sequencing of the 16S rRNA gene. This is the first isolation of $N$. crassostreae from shellfish in European waters. The near full-length 16S rRNA sequence of this Dutch Nocardia sp. isolate was identical to other known N. crassostreae isolates from the west coast of North America. The primary cause of oyster mortality was thought to be the physiological stress from environmental conditions, including prolonged high water temperatures and low oxygen levels. The multiple bacterial species isolated from the diseased Pacific oysters may have been a secondary cause.
\end{abstract}

KEY WORDS: Nocardia crassostreae · Vibrio aestuarianus · Crassostrea gigas · Ostrea edulis · Summer mortalities

Resale or republication not permitted without written consent of the publisher

\section{INTRODUCTION}

Summer mortalities in the Pacific oyster Crassostrea gigas often have a complex aetiology, including factors such as environmental conditions, physiological status of the host and pathogenic agents (Beattie et al. 1988, Lacoste et al. 2001, Paillard et al. 2004, Friedman et al. 2005). Nocardiosis associated with Pacific oyster mortalities has been reported since the mid-twentieth century in Hiroshima and Matsushima Bay in Japan (Numachi et al. 1965, Koganezawa 1975) and on the west coast of North America in California, Washington state and British Columbia (Sindermann \& Rosenfield 1967, Elston 1993, Bower et al. 2005). In general, the losses were attributed to physiological stress induced by gonad development and rapid metabolism under high-nutrient and warm-water conditions (Imai et al. 1965, 1968, Koganezawa 1975). However, Friedman \& Hedrick (1991) and Friedman et al. (1991) found a cor- relation between the occurrence of Pacific oyster nocardiosis and summer mortalities. They induced characteristic histopathological changes and mortality by injecting the bacterium into healthy Pacific oysters, and suggested Pacific oyster nocardiosis to be a causal factor in summer mortalities in certain areas.

Pacific oysters affected by nocardiosis show no or only a few external and non-pathognomonic signs of infection: yellow-green abscesses on the surface of the mantle, gill, muscle and heart. Typical clusters of bacteria can be observed in almost every tissue of infected oysters but are primarily found within the connective tissue surrounding the digestive tract and the gonadal follicles. This is associated with a massive infiltration of host haemocytes surrounding the clusters of bacteria in the affected areas (Elston et al. 1987, Friedman et al. 1991, Bower et al. 2005).

The Gram-positive actinomycete was isolated by Friedman \& Hedrick (1991) and typed to the genus 
Nocardia. The disease was renamed Pacific oyster nocardiosis (PON). In a subsequent study the bacterium was described as Nocardia crassostreae after further phenotypical characterisation and sequencing of the 16S rRNA gene (Friedman et al. 1998).

Since 2003, bacterial lesions with a Nocardia-like appearance have been observed by histopathology in Pacific oyster and European flat oyster Ostrea edulis samples from routine monitoring for shellfish diseases in the Netherlands. The monitoring was carried out in spring (May-June) and autumn (OctoberNovember) and the Nocardia-like organisms were observed occasionally in the autumn samples at a low prevalence $(<4 \%)$. During summer 2006 when mortalities were occurring in the Pacific oyster population of Lake Grevelingen, samples were taken to screen for the presence of pathogens. In the present case study the identification of the Nocardia-like organisms is described and possible environmental factors contributing to the appearance of the bacterium are discussed. Histopathological findings were confirmed by isolation of the bacterium and the use of a specific PCR for detection of Nocardia crassostreae (Bower et al. 2005). As 16S rRNA gene sequencing can provide a useful tool for classification and identification of species belonging to the genus Nocardia (Roth et al. 2003, Brown-Elliott et al. 2006), the 16S rRNA gene sequence of the isolate was determined.

\section{MATERIALS AND METHODS}

Sample collection. On 4 August 2006, Pacific oysters Crassostrea gigas were collected by the fisheries authorities from 7 commercial sites in Lake Grevelingen, the Netherlands. The oysters were collected by trawling with a $1 \mathrm{~m}$ wide dredge at depths ranging from 2.7 to $6 \mathrm{~m}$. Empty shells with no fouling on the internal valve surfaces were counted to estimate the magnitude of recent mortalities. At each of these sites a moderate to heavy mortality rate (up to $91 \%$ ) was recorded. In total 36 oysters were collected for further investigation in the laboratory.

Bacterial isolation and histological processing. The collected oysters were opened in the laboratory and gross clinical signs were noted. Haemolymph was withdrawn from oysters with clinical lesions as described by Friedman \& Hedrick (1991). Briefly, the pericardial membrane was disinfected with a cotton swab with $70 \%$ ethanol. Haemolymph was aspirated from the heart with a sterile needle and syringe. One drop of haemolymph was inoculated onto heart infusion agar with $5 \%$ sheep blood (HIS agar) and incubated at $22^{\circ} \mathrm{C}$ for $2 \mathrm{wk}$.
For histology, a transverse section of the tissue, including digestive diverticulae, mantle and gills, was preserved in Davidson's solution for at least $24 \mathrm{~h}$ at room temperature. Subsequently, oyster tissues were embedded in paraffin blocks, and 4 to $5 \mu \mathrm{m}$ tissue sections were deparaffinised, stained with haematoxylin and eosin (H\&E) and viewed under light microscopy. Selected specimens were also examined after staining with Gram and Ziehl-Neelsen (ZN) acid-fast stains.

DNA isolation and PCR. DNA was isolated by suspending a single bacterial colony in $1 \mathrm{ml}$ distilled water. The sample was thoroughly mixed on a vortex followed by centrifugation at $16249 \times g$ for $5 \mathrm{~min}$. The pellet was resuspended in $100 \mu \mathrm{l}$ distilled water and boiled for $10 \mathrm{~min}$. The lysate was used as a template for the PCR reactions in a 1:100 dilution in distilled water. Two primer sets for detection of the Nocardia crassostreae 16S rRNA gene were used: (1) general Nocardia spp. primers Nosp.F01 (5'-AGCGCAAGTGACGGTACCT G3') + Nosp.R01 (5'-CCCTCTGTACCGGCCATTGT-3') with an expected product size of $765 \mathrm{bp}$ (A. Gee pers. comm.) and (2) specific N. crassostreae primers NC-990F (5'-GGAAAGCCGTAGAGATGC-3') + NC-1409R (5'CCTTACGGGTTAGGCCAG-3') with an expected product size of $453 \mathrm{bp}$ (Bower et al. 2005).

For each PCR reaction a mixture was prepared containing $1 \times$ concentrated PCR buffer, $2 \mathrm{mM} \mathrm{MgCl}_{2}$, $0.2 \mathrm{mM}$ of each deoxynucleotide (dNTP mixture, Takara Bio), $0.4 \mu \mathrm{M}$ of each primer (Eurogentec) and 2 units of Taq DNA Polymerase (Invitrogen) in distilled water. Aliquots $(5 \mu \mathrm{l})$ of the 1:100 diluted lysate were added to the mix to make a final volume of $50 \mu \mathrm{l}$. The PCR conditions were 2 min at $94^{\circ} \mathrm{C}$, followed by 40 cycles of $30 \mathrm{~s}$ at $94^{\circ} \mathrm{C}, 30 \mathrm{~s}$ at $58^{\circ} \mathrm{C}, 45 \mathrm{~s}$ at $72^{\circ} \mathrm{C}$ and a final extension for $7 \mathrm{~min}$ at $72^{\circ} \mathrm{C}$ in a GeneAmp 9700 (Applied Biosystems). The PCR product was visualised on a $2 \%$ agarose E-gel (Invitrogen) under UV light.

Sequencing and sequence data analysis. To sequence the 16S rRNA gene of the isolated bacteria, DNA was extracted as described ('DNA isolation and $\left.\mathrm{PCR}^{\prime}\right)$. Sequences were obtained using the 16S rRNA bacterial identification kit Microseq Full Gene (Applied Biosystems) according to the manufacturer's protocol. The PCR reaction products were purified using a QIAquick PCR purification kit (QIAGEN). Following the sequencing reaction the products were purified over Sephadex G50 Superfine (Pharmacia) and subsequently sequenced on an ABI Prism 3100 Avant Genetic Analyzer (Applied Biosystems). The 16S rRNA gene was sequenced in duplicate to ensure accuracy of the sequence data. The nucleotide sequences obtained were analysed using Sequencher 4.6 (Gene Codes) and compared with sequences available in GenBank using BLAST (Altschul et al. 1990). The obtained 16S rRNA sequence was submitted to GenBank as isolate NL15- 
17, and was given accession number EF219156. For construction of a phylogenetic tree, nucleotide sequences of Nocardia crassostreae with the following accession numbers were retrieved from GenBank (www.ncbi.nlm.nih.gov/): U92799 (strain RB1), U92800 (strain OB3P) and AF430049 (JCM 10500; type strain $\mathrm{NB} 4 \mathrm{H}$ ). Also retrieved were the $16 \mathrm{~S}$ rRNA sequences of type strains from other Nocardia species: N. abscessus (AF430018), N. africana (AF430054), N. asteroides (AF430019), N. brasiliensis (AF430038), N. carnea (AF430035), N. cyriacigeorgica (AF430027), N. farcinica (AF430033), N. nova (AF430028), N. otitidiscaviarum (AF430067), N. paucivorans (AF430041), N. pseudobrasiliensis (AF430042), N. pseudovaccinii (AF430046), N. salmonicida (AF430050), N. seriolae (AF430039), N. transvalensis (AF430047), N. uniformis (AF430044), N. vaccinii (AF430045), N. veterana (AF430055) and N. vinacea (AB024312). Mycobacterium bovis (BX248338) was used as the outgroup. The sequences were aligned using the ClustalX 1.81 program (Thompson et al. 1997) and the trees generated with MEGA 2.1 software (Kumar et al. 2001) using the neighbor-joining method (Saitou \& Nei 1987).

\section{RESULTS}

\section{Gross clinical and histopathological observations}

Of the 36 Pacific oysters tested, 2 showed clinical lesions and were suspected to have a bacterial infection (hereafter referred to as oysters 8-1 and 15-17). The lesions had a focal appearance, and consisted of yellow-green nodules on gill and mantle tissue.

Histologically, 6 of the 36 oysters had lesions suggestive of bacterial infections. Of these, 4 resembled the bacterium Nocardia. The Nocardia lesions occurred as a typical focal cluster of bacteria in the centre of a massive accumulation of haemocytes (Fig. 1). The lesions were observed most frequently in the vascular sinuses of the connective tissue surrounding the digestive tract. Frequently the lesions were coalesced to multifocal zones of haemocyte infiltration. In addition to the pathological changes in the connective tissue around the digestive tract, 1 oyster had mass infiltration of haemocytes in the gonads with bacterial foci. In another oyster (oyster 15-17), multi-focal lesions were observed in the gills, and 2 oysters had isolated focal areas in mantle tissue.

Of the 2 oysters with suspected bacterial infections not resembling Nocardia, the first (oyster 8-1) showed severe lesions throughout the gonad tissue and haemocytic infiltration of the mantle tissue. In the second oyster the suspected bacterial infection was concentrated in a focal lesion with a strong haemocytic
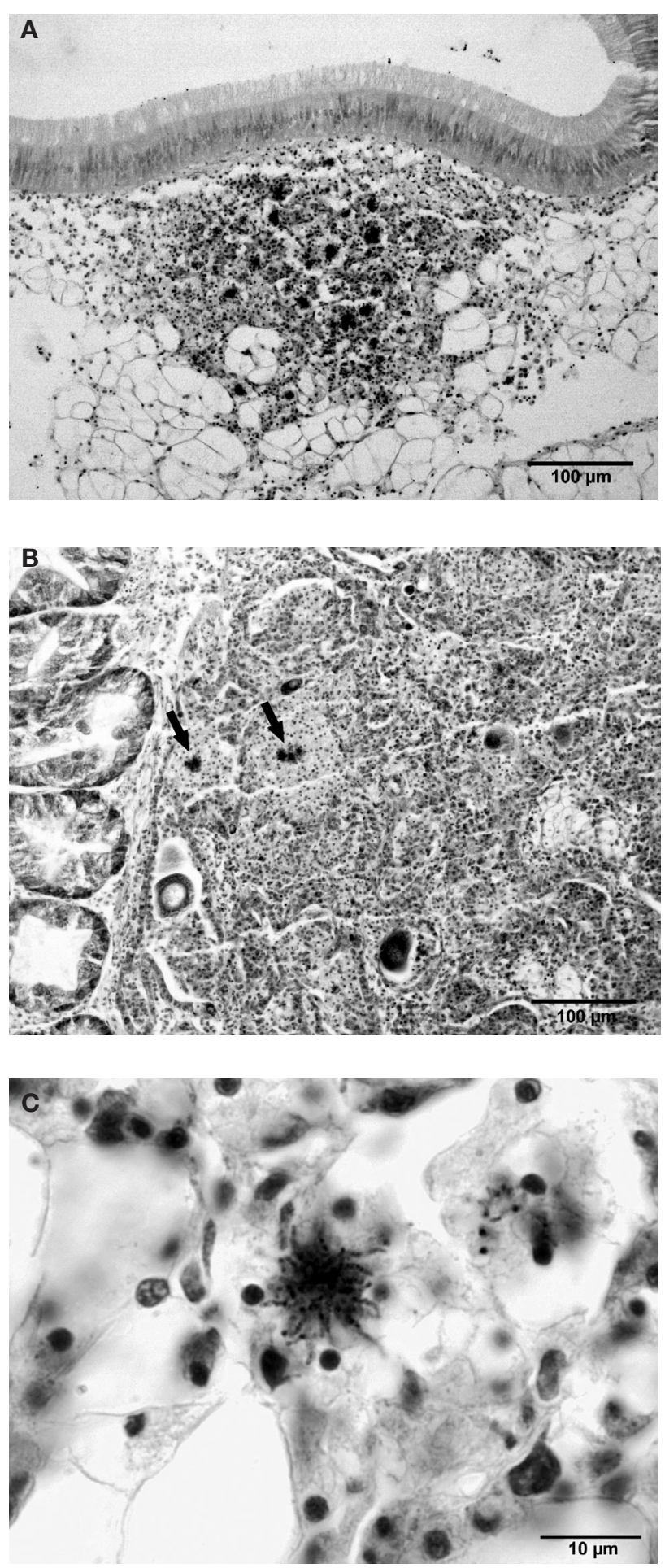

Fig. 1. Crassostrea gigas. Histological sections with nocardiosis. (A) Haemocyte infiltrations around focal clusters of bacteria in the connective tissue surrounding the digestive tract. Ziehl-Neelsen (ZN) stain. (B) Severe haemocyte infiltrations in gonad tissue with focal clusters of bacteria (arrows). ZN stain. (C) Detail of haemocytic infiltration around focal cluster of bacteria. Gram stain 


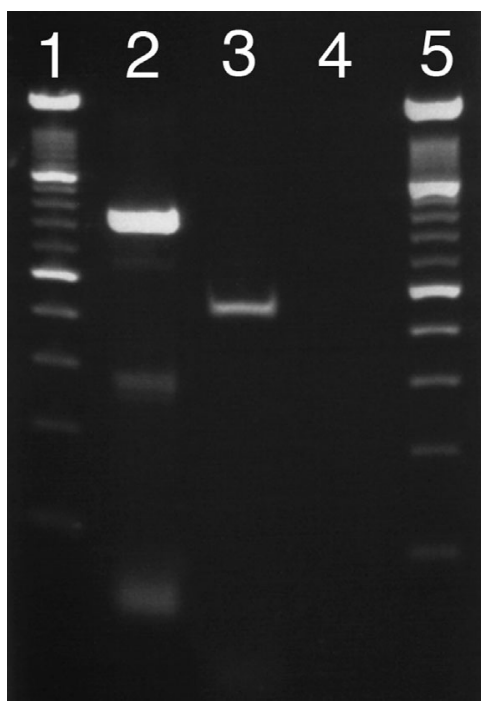

Fig. 2. Nocardia crassostreae. Amplification of 16S rRNA with different primer sets. Lanes 1 and 5: DNA molecular weight marker XIV (100 bp ladder, Roche); Lane 2: primer set Nosp.F01 + Nosp.R01; Lane 3: primer set NC-990F + NC-

1409R; Lane 4: negative control of the PCR reaction wrinkled. The PCRs with the primer sets Nosp.F01 + Nosp.R01 and NC-990F + NC-1409R amplified products of the expected sizes when separated on agarose gels (Fig. 2). Amplification with the Nosp.F01 + Nosp.R01 primer set included an aspecific product of $\sim 280$ bp. For confirmation of this bacterial species, the near full-length sequence (1431 bp) of the 16S rRNA was obtained. The sequence showed $100 \%$ identity with the 16S rRNA sequences of the published Nocardia crassostreae isolates RB1 and OB3 and the type strain JCM 10500 (isolate NB4H). Fig. 3 shows the phylogenetic relationship with these strains and other related Nocardia species.

\section{DISCUSSION}

A number of authors have suggested a possible wide distribution of Nocardia crassostreae (Elston 1993, Bower et al. 2005) as a result of the historical movements and current wide distribution of the Pacific oyster. However, thus far reports on geographical distribution have been limited to Japan and the west coast of infiltration in the mantle tissue. In addition, haemocytic neoplasia was observed in 2 of the 36 oysters.

Sex and maturation status was determined by histology for each oyster. Twothirds (24 out of 36) of the oysters were fully mature. Because of the low number of Nocardia-infected oysters detected by histology, conclusions about the relationship between infection and sex and maturation status would be unreliable.

\section{Bacterial culture and identification}

Haemolymph was taken from the heart of the 2 clinically diseased oysters and inoculated onto HIS agar. From oyster 8-1 a pure bacterial culture was obtained after $3 \mathrm{~d}$ incubation at $22^{\circ} \mathrm{C}$. Sequence analysis of a partial fragment of the $16 \mathrm{~S}$ rRNA gene (419 bp from the 5' end) from this isolate revealed that the bacterium was most closely related to Vibrio aestuarianus, with a 99 to $100 \%$ homology to published V. aestuarianus strains in GenBank.

By Day 10 post-inoculation, the HIS agar plate of oyster 15-17's haemolymph grew a pure culture of a Gram-positive bacterium. The bacterial colonies appeared dry and

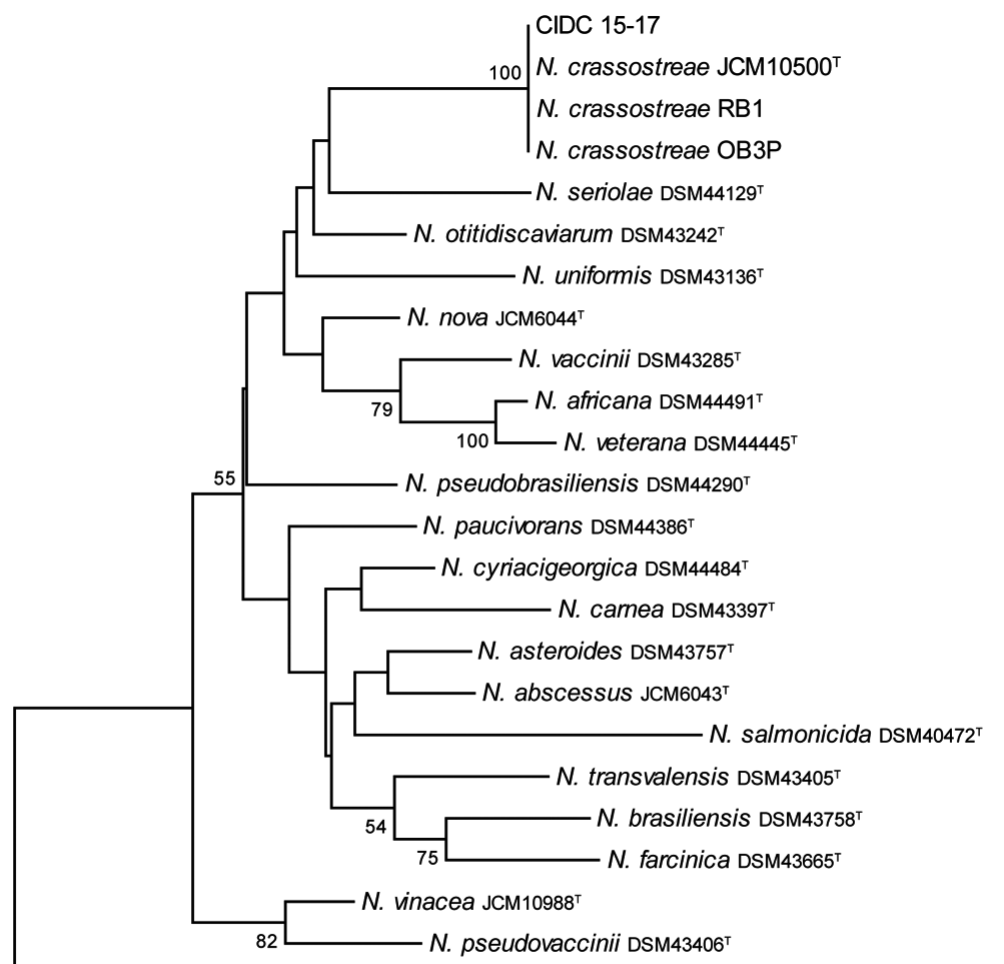

Mycobacterium bovis AF2122/97

$$
\stackrel{\longmapsto}{0.005}
$$

Fig. 3. Phylogenetic neighbor-joining tree generated using 16S rRNA sequences of Nocardia crassostreae isolates and 19 relevant Nocardia species type strains. The tree was rooted using Mycobacterium bovis as the outgroup. Bootstrap values (1000 replications) above $50 \%$ are indicated at the branch nodes 
North America (Koganezawa 1975, Bower et al. 2005). In the present study N. crassostreae is described for the first time in Europe in cultured Pacific oysters. The bacterium was positively identified with a general Nocardia spp. PCR and a previously published $N$. crassostreae-specific PCR. The results were confirmed by sequencing. Based on the conserved $16 \mathrm{~S}$ rRNA sequence, this isolate was identical to the previously sequenced $N$. crassostreae isolates from North America.

The Nocardia crassostreae isolate originated from a diseased Pacific oyster during summer mortality in Lake Grevelingen. This lake is a shallow enclosed estuary with only a very limited inlet of fresh seawater. During the summer, stratification of the water column can take place. Pacific oysters and European flat oysters are cultured together on the sandy or muddy substrate. The characteristics of this area are consistent with observations in Japan and North America where losses due to nocardiosis are most severe in animals reared in shallow, warm, eutrophic embayments (Imai et al. 1968, Friedman \& Hedrick 1991). At the time of the mortalities the surface water in Lake Grevelingen measured 22 to $23^{\circ} \mathrm{C}$ and dissolved oxygen concentration ranged from 5 to $6 \mathrm{mg} \mathrm{O} \mathrm{O}_{2}^{-1}$. These parameters differed from those measured during the same period in 2004 and 2005 when surface waters had a lower temperature and contained more dissolved oxygen (data from the Hydro Meteo Centrum Zeeland, the Netherlands, www.hmcz.nl/). The elevated water temperature and reduced dissolved oxygen levels could have resulted in hypoxic conditions in 2006, thereby impacting oyster health.

In addition to Nocardia crassostreae, Vibrio aestuarianus was isolated from another diseased Pacific oyster in the same area. V. aestuarianus has been described in association with summer mortalities in Pacific oysters in France (Garnier et al. 2007). The isolation of multiple species of pathogenic bacteria together with the summer characteristics of Lake Grevelingen suggest that the onset of the mortalities was primarily caused by environmental conditions such as prolonged elevated water temperatures, low oxygen and eutrophication, and possibly in combination with the maturation status of the oysters. Such conditions could have created growth opportunities for N. crassostreae and pathogenic Vibrio species which, as a secondary cause, contributed to the mortalities. A decrease in the general condition of oysters was thought to contribute to previous summer mortalities of Pacific oysters in the Oosterschelde estuary in the Netherlands. During 1994 and 1995 mortality events, prolonged high water temperatures that started early in the season and coincided with the maturation period of the oysters (P. van Banning unpubl.) were observed. No pathogens were observed in histological investigation of these summer mortalities.
In the present study, Nocardia crassostreae was isolated and identified from a diseased Pacific oyster during a summer mortality event. However, in preceding years histological analysis of Pacific oysters sampled for routine shellfish disease surveillance showed pathological lesions very similar to the lesions of the oyster from which $N$. crassostreae was isolated. The first record of a Nocardia-like organism by histology was in autumn 2003 in 'healthy' Pacific oysters sampled from the Oosterschelde.

The most obvious vector for the introduction of Nocardia crassostreae is the importation of Pacific oysters. The Pacific oyster was introduced to the Netherlands in 1964 and importations of spat from Japan and the USA continued until 1977 (Drinkwaard 1998, Wolff \& Reise 2002). Later, the majority of Pacific oysters were imported from Belgium and France. In 1975, after a very warm summer, the first natural spat fall was recorded in Dutch waters and the Pacific oyster established itself in the following years. Subsequently, importations of Pacific oysters gradually decreased. In recent years the biomass of Pacific oysters increased dramatically in the Oosterschelde, Lake Grevelingen and Wadden Sea (Wolff \& Reise 2002). Apart from the introduction of the oyster species, the gap between the major historical imports and the relatively recent detection of nocardiosis might support the hypothesis of Elston (1993) that the causative bacterium might originate from an environmental source and potentially occurs wherever the Pacific oyster is cultured. N. crassostreae may be a soil saprophyte, as are most species of Nocardia, that only under certain conditions becomes an opportunistic pathogen of live oysters (Friedman et al. 1991, Bower et al. 2005).

In Lake Grevelingen, Pacific oysters are present along with the native European flat oysters Ostrea edulis. In the routine surveillance of shellfish diseases in the autumn of 2004 and 2005, histological analysis showed nocardiosis in European flat oysters with pathological lesions similar to the lesions found in Nocardia crassostreae-infected Pacific oysters. Elston et al. (1987) and Bower et al. (2005) described nocardiosis in European flat oysters cultivated near areas of infected Pacific oysters in Washington state and Malaspina Inlet, British Columbia, respectively. Although no attempts were made in the present study to isolate $N$. crassostreae from European flat oysters, there is strong suspicion that $N$. crassostreae is present in the European flat oyster population in Lake Grevelingen as well.

Further studies are needed to determine the origin, distribution and prevalence of Nocardia crassostreae in Dutch estuaries and to estimate the impact of this species on the oyster population. 
Acknowledgements. We gratefully acknowledge H. Heidekamp, T. Kosten, H. van Damme and A. Groen for collecting the oysters. Furthermore, we thank R. Zwart and A. Bartelse for their skilful preparation of histological slides.

\section{LITERATURE CITED}

Altschul SF, Gish W, Miller W, Myers EW, Lipman DJ (1990) Basic local alignment search tool. J Mol Biol 215:403-410

Beattie JH, Davis JP, Downing SL, Chew KK (1988) Summer mortality of Pacific oysters. Am Fish Soc Spec Publ 18: 265-268

Bower SM, Goh B, Meyer GR, Carnegie RB, Gee A (2005) Epizootiology and detection of nocardiosis in oysters. In: Walker P, Lester RG, Bondad-Reantaso MG (eds) 5th Symp Diseases in Asian Aquaculture, Nov 24-28, 2002, Surfer's Paradise, Queensland. Fish Health Section, Asian Fisheries Society, Manila, p 249-262

Brown-Elliott BA, Brown JM, Conville PS, Wallace RJ Jr (2006) Clinical and laboratory features of the Nocardia spp. based on current molecular taxonomy. Clin Microbiol Rev 19:259-282

Drinkwaard AC (1998) Introductions and developments of oysters in the North Sea area: a review. Helgol Meeresunters 52:301-308

Elston RA (1993) Infectious diseases of the Pacific oyster, Crassostrea gigas. Annu Rev Fish Dis 3:259-276

Elston RA, Beattie JH, Friedman CS, Hedrick RP, Kent ML (1987) Pathology and significance of fatal inflammatory bacteraemia in the Pacific oyster, Crassostrea gigas Thünberg. J Fish Dis 10:121-132

Friedman CS, Hedrick RP (1991) Pacific oyster nocardiosis: isolation of the bacterium and induction of laboratory infections. J Invertebr Pathol 57:109-120

Friedman CS, Beattie JH, Elston RA, Hedrick RP (1991) Investigation of the relationship between the presence of a Gram-positive bacterial infection and summer mortality of the Pacific oyster, Crassostrea gigas Thunberg. Aquaculture 94:1-15

Friedman CS, Beaman BL, Chun J, Goodfellow M, Gee A, Hedrick RP (1998) Nocardia crassostreae sp. nov., the causal agent of nocardiosis in Pacific oysters. Int J Syst Bacteriol 48:237-246

Friedman CS, Estes RM, Stokes NA, Burge CA and others (2005) Herpes virus in juvenile Pacific oysters Crassostrea gigas from Tomales Bay, California, coincides with summer mortality episodes. Dis Aquat Org 63:33-41

Garnier M, Labreuche Y, Garcia C, Robert M, Nicolas JL (2007) Evidence for the involvement of pathogenic bacteria in summer mortalities of the Pacific oyster Crassostrea gigas. Microb Ecol 53:187-196

Editorial responsibility: Eugene Burreson, Gloucester Point, Virginia, USA
Imai T, Numachi K-I, Oizimu J, Sato S (1965) Studies on the mass mortality of the oyster in Matsushima Bay. II. Search for the cause of mass mortality and the possibility to prevent it by transplantation experiment. Bull Tohoku Reg Fish Res Lab 25:25-38

Imai T, Mori K, Sugawara Y, Tamate H, Oizimu J, Itikawa O (1968) Studies on the mass mortality of oysters in Matsushima Bay. VII. Pathogenic investigation. Tohoku J Agric Res 19:250-265

Koganezawa A (1975) Present status of studies on the mass mortality of cultured oysters in Japan and its prevention. In: Fukataki H (ed) Proc 3rd U.S.-Japan Meeting on Aquaculture, Tokyo, Oct 15-16, 1974. Japan Fishery Agency and Japan Regional Fisheries Research Laboratory, Niigata, p 29-34

Kumar S, Tamura K, Jakobsen IB, Nei M (2001) MEGA2: molecular evolutionary genetics analysis software. Bioinformatics 17:1244-1245

Lacoste A, Jalabert F, Malham S, Cueff A and others (2001) A Vibrio splendidus strain is associated with summer mortality of juvenile oysters Crassostrea gigas in the Bay of Morlaix (North Brittany, France). Dis Aquat Org 46:139-145

Numachi KI, Oizimu J, Sato S, Imai T (1965) Studies on the mass mortality of the oyster in Matsushima Bay. III. The pathological changes of the oyster caused by Grampositive bacteria and their frequency of their infection. Bull Tohoku Natl Fish Res Inst 25:39-48

Paillard C, Le Roux F, Borrego JJ (2004) Bacterial disease in marine bivalves, a review of recent studies: trends and evolution. Aquat Living Resour 17:477-498

Roth A, Andrees S, Kroppenstedt RM, Harmsen D, Mauch H (2003) Phylogeny of the genus Nocardia based on reassessed 16S rRNA gene sequences reveals underspeciation and division of strains classified as Nocardia asteroides into three established species and two unnamed taxons. J Clin Microbiol 41:851-856

Saitou N, Nei M (1987) The neighbor-joining method: a new method for reconstructing phylogenetic trees. Mol Biol Evol 4:406-425

Sindermann CJ, Rosenfield A (1967) Principal diseases of commercial important marine bivalve Mollusca and Crustacea. Fish Bull (Wash DC) 66:335-385

Thompson JD, Gibson TJ, Plewniak F, Jeanmougin F, Higgins DG (1997) The ClustalX windows interface: flexible strategies for multiple sequence alignment aided by quality analysis tools. Nucleic Acids Res 25:4876-4882

Wolff WJ, Reise K (2002) Oyster imports as a vector for the introduction of alien species into northern and western European coastal waters. In: Leppäkoski E, Gollasch S, Olenin S (eds) Invasive aquatic species of Europe. Distribution, impacts and management. Kluwer Academic Publishers, Dordrecht, p 193-205

Submitted: November 22, 2007; Accepted: May 16, 2008 Proofs received from author(s): July 4, 2008 